\title{
Erratum to: Optically reconfigurable Sierpinski fractal antennas for RoF based communication systems
}

\author{
Ayhan Yazgan · Haydar Kaya • I. Hakki Cavdar
}

Published online: 7 January 2015

(C) Springer Science+Business Media New York 2015

\section{Erratum to: Telecommun Syst}

\section{DOI 10.1007/s11235-014-9905-4}

The published article contains an error in the second sentence of the section "5.2 Experimental results". The value " $120 \mathrm{~W}$ " should be " $120 \mathrm{~mW}$ ". The sentence should read as below.

In this experiment, $808 \mathrm{~nm}$ and $120 \mathrm{~mW}$ laser with fiber pigtail and a silicon switch are needed to realize the optical part of this experiment.

The online version of the original article can be found under doi:10.1007/s11235-014-9905-4.

A. Yazgan $(\varangle) \cdot$ H. Kaya $\cdot$ I. H. Cavdar

Department of Electrical-Electronics Engineering, Karadeniz Technical University, Trabzon 61080, Turkey

e-mail: ayhanyazgan@ktu.edu.tr 